\title{
Study of Antiviral Activity of Metabolites of a New Serratia species K-57 Strain
}

\section{I. Puchkova, I. S. Andreeva, N. A. Mazurkova, E. I. Filippova, and A. S. Safatov}

Translated from Byulleten'Eksperimental'noi Biologii i Meditsiny, Vol. 168, No. 10, pp. 484-487, October, 2019 Original article submitted June 4, 2019

The results of studies of a newly isolated Serratia species K-57 strain are presented. The strain is characterized by antiviral activity towards human influenza $\mathrm{A} / \mathrm{Aichi} / 2 / 68 / \mathrm{H} 3 \mathrm{~N} 2$, vaccinia, mouse smallpox, and herpes simplex-2 viruses. The detected characteristics of the strain, including the data on activities on nucleolytic enzymes, recommend it for the development of therapeutic and preventive antiviral drugs.

Key Words: Serratia genus nucleases; human influenza A/H3N2 virus; mouse smallpox; vaccinia; herpes simplex-2 viruses

Nucleases exhibit antiviral activity in vitro. Ribonucleases were found to exhibit antiviral activity towards RNA-containing viruses (influenza, poliomyelitis, and tick-borne encephalitis viruses), while deoxyribonucleases suppress reproduction of DNA-containing viruses $[5,7,9]$.

Pharmaceutical nuclease preparations are used in clinical practice for the treatment of viral diseases: ribonuclease is used in tick-borne encephalitis, deoxyribonuclease - in herpetic keratitis, acute catarrhal inflammation of the upper airways of adenoviral nature and in herpes- 1 and -2 [3,5]. Studies aimed at isolation and characterization of secreted RNases of Pseudomonas genus bacteria are in progress [9]. Extracellular $B$. cereus ribonuclease is active towards tobacco mosaic virus [10]. Injection of $B$. intermedius RNase to animals infected with street rabies virus has protected $40 \%$ guinea pigs and $50-70 \%$ rabbits [1]. Endogluquine, a preparation based on $S$. marcescens strain endonuclease, is used for prevention and therapy

Vector State Research Center of Virology and Biotechnology, Koltsovo, Novosibirsk region, Russia. Address for correspondence: puchkova@vector.nsc.ru. L. I. Puchkova of viral infections of bees [3]. The mechanism of antiviral activity of nucleases is related to hydrolysis of nucleic acids by the endonucleolytic mechanism to mono-, di-, tri-, tetra-, and oligonucleotides [4].

We studied the characteristics of a new strain of Serratia sp. K-57, including its nuclease activities, and evaluated the possibility of using its metabolites in the antiviral drug biotechnology.

\section{MATERIALS AND METHODS}

Serratia sp. K-57 strain is isolated as a result of screening of natural bacterial isolates for nucleolytic enzymes by means of selection of colonies in selective medium with DNA and Toluidine Blue (Difco) [2]. The strain is deposited at Collection of Bacteria, Bacteriophages, and Fungi, Vector State Research Center of Virology and Biotechnology.

The taxonomic group of the studied bacterium was determined by analyzing its phenotypic characteristics by standard methods [2,8], and genomic identification was performed by studying nucleotide sequences of PCR products corresponding to $16 \mathrm{~S}$ rRNA gene at the Interinstitutional DNA Sequenc- 
ing Center Siberian Division of Russian Academy of Sciences (Novosibirsk).

Serratia $s p$. K-57 strain was cultured in liquid or solid LB medium ( $\mathrm{pH} 7.0-7.2$; Difco) at $37^{\circ} \mathrm{C}$ for $18-$ 24 h. Serratia sp. K-57 subcultures were maintained by regular reinoculations in agarized LB medium.

Nonspecific nucleases were detected in the strain as described previously [6]. Phages 1 and T7 DNA (SibEnzyme) served as substrates. Nuclease activities were measured by accumulation of $4 \% \mathrm{HClO}_{4}$ soluble product catalyzing the formation of a unit of acidsoluble products at $\lambda=260 \mathrm{~nm}$ over $1 \mathrm{~h}$ at $37^{\circ} \mathrm{C}$, was taken for a unit of enzyme activity.

The preparations containing the secreted nucleases were obtained by culturing Serratia $s p$. K-57 strain in liquid LB medium on a KT-104 thermostat shaker at $150 \mathrm{rpm}$ and $37^{\circ} \mathrm{C}$ during $18 \mathrm{~h}$. The resultant culture fluid (CF) was centrifuged at $10,000 \mathrm{rpm}$ for $30 \mathrm{~min}$ using a JA-21 centrifuge (Beckman). The supernatant was sterilized by ultrafiltration through 0.45 - and $0.2-\mu$ Whatman filters and used for testing as the antiviral drug.

Intracellular nucleases were studied as follows: 1 $\mathrm{g}$ wet biomass was resuspended in $4 \mathrm{ml}$ sterile distilled water, processed on an MSE ultrasonic disintegrator $(4 \times 30 \mathrm{sec}$, with $30 \mathrm{sec}$ intervals $)$, and centrifuged at 10,000 rpm in an Eppendorf microcentrifuge. The cell extract free from cell debris was sterilized by ultrafiltration. The resultant preparations were stored at $-20^{\circ} \mathrm{C}$ until use.

For evaluation of the toxicity and antiviral activity of the resultant preparations towards RNA-containing viruses, human A/Aichi/2/68 (H3N2) influenza virus (titer $10^{7.5} \mathrm{lg} \mathrm{TCD}_{50} / \mathrm{ml}$ ) and continuous MDCK culture were used. For evaluation of the toxicity and antiviral activity of cell metabolites towards DNA-containing viruses, we used continuous Vero culture and the following viruses: mouse smallpox (MSP, strain K-1), titer $10^{4.6} \mathrm{lg} \mathrm{PFU} / \mathrm{ml}$; vaccinia (VV, strain L-IVP), $10^{4.5}$ lg PFU/ml; herpes simplex type 2 (HSV-2, strain MS), titer $10^{4.5} \mathrm{lg} \mathrm{TCD}_{50} / \mathrm{ml}$ (all viruses from Collection of Microorganisms, Vector State Research Center of Virology and Biotechnology). Antiviral activity of the experimental samples was studied according to the prophylactic protocol of analysis.

The data were processed by Student's $t$ test and expressed as the arithmetic means $(M)$ and standard deviations $(S D)$ and $95 \%$ confidence intervals $(95 \% \mathrm{CI})$. The differences were significant at $p \leq 0.05$.

\section{RESULTS}

Bacterial isolate K-57 formed significant zones of nuclease activity in selective medium, and hence, this strain was chosen for further research. Molecular ge-
TABLE 1. Phenotypical Signs of Serratia Genus Bacteria and Bacterium Strain K-57

\begin{tabular}{|c|c|c|c|}
\hline \multicolumn{2}{|c|}{ Sign } & $\begin{array}{c}\text { Serratia } \\
\text { Genus }\end{array}$ & Strain K-57 \\
\hline \multicolumn{2}{|c|}{ Gelatin hydrolysis } & + & + \\
\hline \multicolumn{2}{|c|}{ Pigment } & $+1-$ & - \\
\hline \multicolumn{2}{|c|}{ Catalase } & + & + \\
\hline \multicolumn{2}{|c|}{ Amylase } & - & - \\
\hline \multicolumn{2}{|c|}{ Oxidase } & - & - \\
\hline \multicolumn{2}{|c|}{ Simmons Citrate } & + & + \\
\hline \multicolumn{2}{|l|}{ MR } & $>70 \%$ & - \\
\hline \multicolumn{2}{|l|}{ VR } & + & + \\
\hline \multicolumn{2}{|c|}{ Indole } & - & - \\
\hline \multicolumn{2}{|c|}{ Hydrogen sulfide } & - & - \\
\hline \multirow[t]{5}{*}{ Acid: } & glucose & + & + \\
\hline & maltose & + & + \\
\hline & mannitose & + & + \\
\hline & sucrose & + & + \\
\hline & lactose & - & - \\
\hline \multicolumn{2}{|c|}{ Nitrate reduction } & + & + \\
\hline \multicolumn{2}{|c|}{ DNase } & + & + \\
\hline \multicolumn{2}{|c|}{ Urease } & $>70 \%$ & - \\
\hline \multicolumn{2}{|c|}{ Phenylalanindeaminase } & - & - \\
\hline \multicolumn{2}{|c|}{ Lysindecarboxylase } & + & + \\
\hline
\end{tabular}

Note. "+" positive reaction; "-" negative reaction. MR: methyl red reaction; VR: Voges-Proskauer reaction.

netic analysis of the nucleotide sequence of rRNA $16 \mathrm{~S}$ showed the appurtenance of bacterium K-57 to Serratia genus $(99 \%$ similarity by fragments of identified sequences). The morphophysiology and biochemistry of bacterium K-57 (Table 1) confirmed its appurtenance to Serratia genus. By the sum of phenotypical and genomic characteristics, bacterium K-57 was identified as Serratia sp. and called Serratia sp. K-57.

Testing of Serratia sp. K-57 strain in selective media containing nucleic acids demonstrated its RNase and DNase activities. The results of phages 1 and T7 DNA hydrolysis by Serratia $s p$. K-57 CF-based preparations and cell extract were presented in Figure 1.

Measurement of nuclease activity of Serratia $s p$. K-57 strain showed that the RNase activity of CF was $280.5 \mathrm{U} / \mathrm{ml}$ and the activity of cell extract was 270.8 $\mathrm{U} / \mathrm{ml}$, or $3070 \mathrm{U} / \mathrm{g}$ wet biomass.

The data suggest that Serratia sp. K-57 strain exhibits DNase activity and hydrolyzes salmon milt DNA and DNA of phage T7 and phage $\lambda$. In addition, preparations of Serratia $s p$. K-57 strain CF, diluted 10 - and 100-fold, effectively hydrolyzed substrate DNA. 

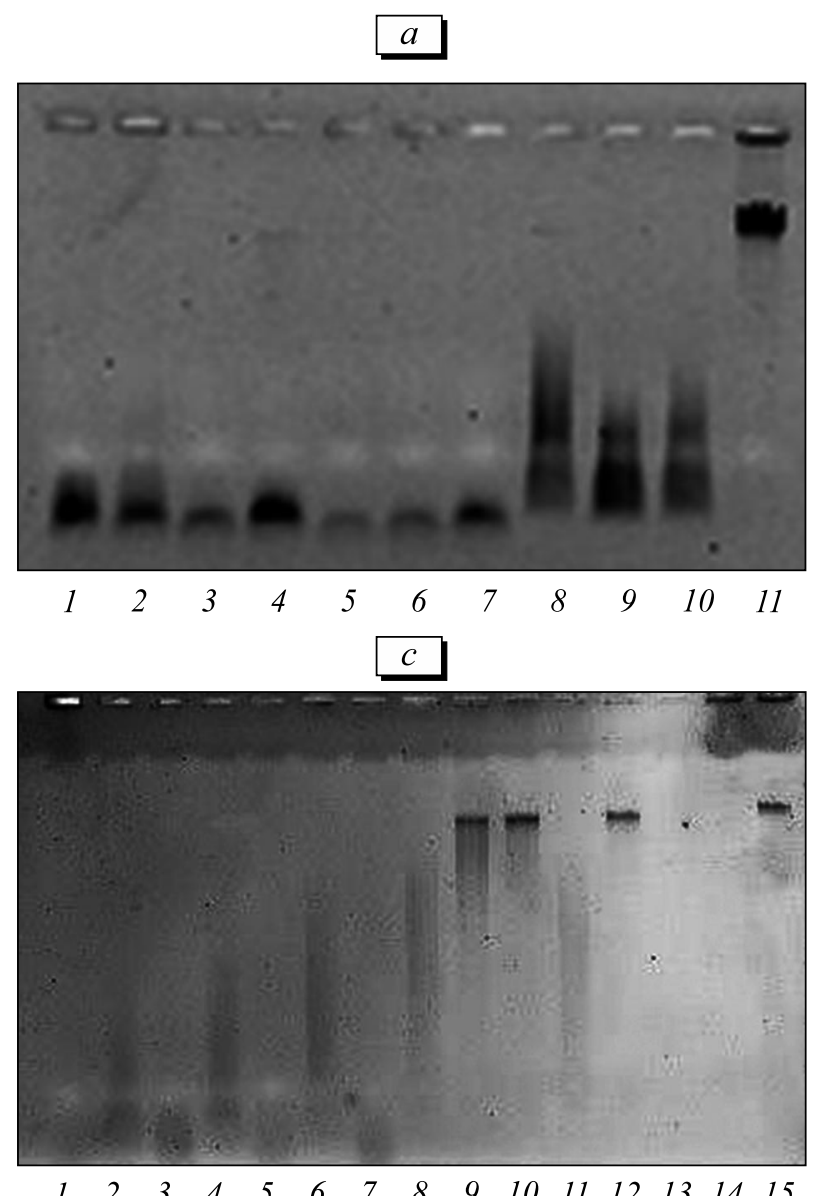

The antiviral activity of preparations based on the Serratia sp. K-57 CF and cell extract was studied using 10-fold dilutions, exhibiting no toxicity towards the cell cultures used. Studies of antiviral activity towards RNA viruses showed that Serratia sp. K-57 $\mathrm{CF}$ and cell extract inhibited significantly the multiplication of influenza A/Aichi/2/68 (H3N2) virus in MDCK culture. The indexes of this virus reproduction inhibition (difference between virus titer $\mathrm{lg}$ in control (without sample) and experiment) under the effects of experimental samples of $\mathrm{CF}$ and cell extract were 2.7 and $2.6 \mathrm{lg}$, with RNase activities in specimens of

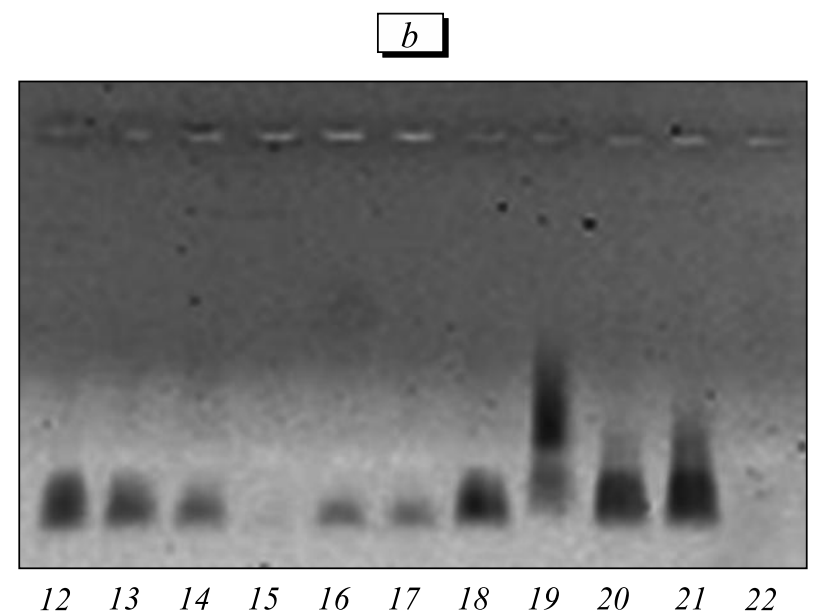

Electrophoregram of phages $\lambda$ and T7 DNA hydrolysis by CFbased samples of Serratia sp. K-57 clones. a) Hydrolysis of phage T7 DNA by CF preparations from clones of Serratia $s p$. K-57 strain (1-7); 11) phage T7 DNA control. b) Hydrolysis of phage $\lambda$ DNA by CF preparations from the same clones (12-18); 22) CF preparation from control S. marcescens B-10 M-1 strain. c) Hydrolysis of phage 1 DNA by CF preparations from Serratia sp. K-57 clones 1-4. Serratia sp. K-57 CF preparations were used in dilution $1: 10(1,3,5,7)$ and $1: 100(2,4,6,8) ; 13,14) S$. marcescens strain B10 M1 CF control; 15) phage 1 DNA control.

CF and cell extract 41.7 and $380.0 \mathrm{U} / \mathrm{ml}$, respectively (Table 2).

The sample based on Serratia sp. K-57 CF reduced significantly the efficiency of multiplication in Vero cells of all DNA genome viruses used in the study (Table 2). The indexes of virus multiplication inhibition in Vero cells under the effect of this sample were $2.4,2.0$, and $2.0 \mathrm{lg}$ for mouse smallpox, vaccinia, and HSV-2 viruses, respectively.

The results recommend strain Serratia sp. K-57 as a prospective prophylactic antiviral drug with complex activities.

TABLE 2. Antiviral Activities of Serratia sp. K-57 CF and Cell Extract towards RNA and DNA Viruses in Continuous Cell Cultures

\begin{tabular}{l|c|c|c|c|c}
\hline \multirow{2}{*}{ Sample } & \multirow{2}{*}{$\begin{array}{c}\text { RNase } \\
\text { activity, } \\
\text { U/ml }\end{array}$} & $\begin{array}{c}\text { Virus titer in MDCK, Ig } \\
\mathrm{TCD}_{50} / \mathrm{ml}(M \pm S D)\end{array}$ & \multicolumn{3}{|c}{ Virus titer in Vero cells: } \\
\cline { 3 - 6 } & & $\begin{array}{c}\text { influenza A/H3N2 virus } \\
(n=3)\end{array}$ & $\mathrm{MSV}(k=6)$ & $\mathrm{VV}(k=6)$ & $\mathrm{HSV}-2(n=3)$ \\
\hline CF & 414.7 & $2.4 \pm 0.1^{*}$ & $2.2 \pm 0.2^{*}$ & $2.5 \pm 0.1^{*}$ & $3^{\prime}$ \\
Cellular extract & 380.0 & $2.5 \pm 0.2^{*}$ & N.s. & N.s. & N.s. \\
Virus control & - & $5.1 \pm 0.1$ & $4.6 \pm 0.1$ & $4.5 \pm 0.2$ & $5.3 \pm 0.1$ \\
\hline
\end{tabular}

Note. N.s.: not studied; $k$ : number of wells with monolayer of cells infected with virus in various dilutions; $n$ : number of experiment repeats; MSV: mouse smallpox virus; VV: vaccinia virus; HSV-2: type 2 herpes simplex virus. ${ }^{*} p \leq 0.05$ in comparison with respective control. 
The study was carried out within a framework of work on theme GZ 7/19 of The Federal Service for Supervision of Consumer Rights Protection and $\mathrm{Hu}-$ man Well-Being of Russian Federation.

\section{REFERENCES}

1. Gribencha SV, Potseluyeva LA, Barinsky IF, Deyev SM, Balandin TG, Leshchinskaya IB. Antiviral activity of Bacillus intermedius RNAase in guineapigs and rabbits infected with outdoor rabies virus. Vopr. Virusol. 2006;51(5):41-44. Russian.

2. Manual of Methods for General Bacteriology. Gerhardt P, ed. Moscow, 1983-1984. Vol. 1-3.

3. Detinenko LD, Klimenko VP, Podgornyj VF, Alikin JS, Masycheva VI, Grobov OF, Batuev JM. Patent RU No. 2038776. Agent for prophylaxis and treatment of virus diseases of bee and for stimulating growth of bee colony. Published July 9, 1995.

4. Filimonova MN, Ershova EV, Safin JI, Tojmentseva AA, Shabaeva JD, Susarova AN, Valeev AR, Ugrjumova VS, Ravilov AZ, Karimullina IG, Fatkullova AA, Shishko AA, Karimov MZ. Patent RU No. 2337139. Germicide. Bull. No. 30. Published October 27, 2008.
5. Klopotenko LL. Patent RU No. 2494757. Pharmaceutical composition containing enzyme deoxyribonuclease, alphafetoprotein and glycyrrhizic acid or salts thereof: ammonium or dipotassium or trisodium glycyrrhizinate. Bull. No. 28. Published October 10, 2013.

6. Puchkova LI, Makarevich EV, Ibragimova ZhB, Selivanova MA, Solovyanova NA, Mazurkova NA, Andreeva IS. Antiviral activity of water-soluble metabolites of strain Aeromonas bestiarum BP-1010. Sovremen. Probl. Nauki Obrazovaniya. 2015;(3):567. Russian.

7. Shah Mahmud R, Ilinskaya ON. Antiviral Activity of Binase against the Pandemic Influenza A (H1N1) Virus. Acta Naturae. 2013;5(4):44-51.

8. Bergey's Manual of Determinative Bacteriology. Baltimore; London. 1997. Vol. 1.

9. Kamble KD, Pinjare VS. Extra cellular ribonuclease production from Pseudomonas species. Asian J. Exp. Biol. Sci. 2012;3(4):810-815.

10. Zhou WW, Niu TG. Purification and some properties of an extracellular ribonuclease with antiviral activity against tobacco mosaic virus from Bacillus cereus. Biotechnol. Lett. 2009;31(1):101-105. 